\title{
Mathematical Modelling of Blanch-Assisted Drying of Pomegranate (Punica granatum) Arils in a Hot-Air Drier
}

\author{
Adegoke Olusesan Adetoro ${ }^{1}$, Alemayehu Ambaw Tsige ${ }^{1}$, Umezuruike Linus Opara ${ }^{1}$ and \\ Olaniyi Amos Fawole 1,2,* \\ 1 Department of Horticultural Science, Postharvest Technology Research Laboratory, South African Research \\ Chair in Postharvest Technology, Stellenbosch University, Private Bag X1, Stellenbosch 7602, South Africa; \\ 21412944@sun.ac.za (A.O.A.); tsige@sun.ac.za (A.A.T.); opara@sun.ac.za (U.L.O.) \\ 2 Department of Botany and Plant Biotechnology, University of Johannesburg, P.O. Box 524, Auckland Park, \\ Johannesburg 2006, South Africa \\ * Correspondence: olaniyif@uj.ac.za; Tel.: +27-11-559-7237; Fax: +27-11-559-2411
}

Received: 22 April 2020; Accepted: 18 May 2020; Published: 20 May 2020

\begin{abstract}
The effect of blanching conditions on the hot-air drying kinetics of three pomegranates (cvs. "Acco", "Herskawitz" and "Wonderful") were assessed. Water blanching conditions considered were $90^{\circ} \mathrm{C}$ for $30 \mathrm{~s}, 90^{\circ} \mathrm{C}$ for $60 \mathrm{~s}, 100^{\circ} \mathrm{C}$ for $30 \mathrm{~s}$ and $100{ }^{\circ} \mathrm{C}$ for $60 \mathrm{~s}$. The drying experiments were carried out at $60^{\circ} \mathrm{C}, 19.6 \%$ relative humidity and at a constant air velocity of $1.0 \mathrm{~m} \mathrm{~s}^{-1}$. The experimental curves were fitted to seven different drying models. For the Acco cultivar, the drying behaviour was best predicted by the Logarithmic and Page model for blanched $\left(R^{2}\right.$ ranging between 0.9966 and $0.9989)$ and unblanched $\left(R^{2}=0.9918\right)$ samples, respectively. Furthermore, for the Herskawitz cultivar, Logarithm, Page and Midili models were most suitable for predicting drying behaviour of both blanched and unblanched samples. Also, for the Wonderful cultivar, Logarithm and Midili models were most accurate for predicting the drying behaviour for both blanched and unblanched samples amongst other models. The blanched samples dried faster with shorter drying times: "Acco" $(7 \mathrm{~h})$, "Herskawitz" (8 h), and "Wonderful" (7 h), compared to the unblanched samples, which dried after 15, 20 and $11 \mathrm{~h}$, respectively. Effective diffusion coefficient of moisture in pomegranate arils ranged from $4.81 \times 10^{-9}$ and $1.11 \times 10^{-8} \mathrm{~m}^{2} \mathrm{~s}^{-1}$ for the Acco cultivar, for the Herskawitz cultivar; $3.29 \times 10^{-9}$ and $1.01 \times 10^{-8} \mathrm{~m}^{2} \mathrm{~s}^{-1}$ and for the Wonderful cultivar; $5.83 \times 10^{-9}$ and $1.09 \times 10^{-8} \mathrm{~m}^{2}$ $\mathrm{s}^{-1}$. Overall, blanching resulted in low energy consumption during drying of pomegranate arils. In addition, the Logarithmic model generally showed an appropriate model for blanched samples regardless of cultivar. For unblanched samples, the Page model was more appropriate for "Acco" and "Herskawitz", while the Midili model was appropriate for "Wonderful". Therefore, this study provided science-based and practical drying conditions for the investigated pomegranate cultivars.
\end{abstract}

Keywords: cultivars; drying kinetics; blanching; effective diffusivity; empirical models

\section{Introduction}

Pomegranate (Punica granatum) fruit consumption has continued to gain global interest among consumers due to its rich nutritional properties and high content of polyphenols [1,2]. It is a good source of phenolic compounds including flavonoids (anthocyanins and flavonols), condensed tannins (proanthocyanidins) and hydrolysable tannins (ellagitannins and gallotannins) [3]. However, pomegranates arils are highly perishable, with a shelf life of 5 to 8 days [4]. This limits pomegranate consumption and availability during the off-season. Drying is one of the oldest methods used to preserve food commodities [5]. Drying has been shown to preserve and add value to pomegranates 
by transforming fresh arils into a nutrient-dense snack called anardana, with improved sensory attributes [6]. It has an extensive shelf life in proper packaging, substantially reduced fruit weight during transportation and lower handling and storage costs compared to fresh fruit [7].

The drying of food materials involves simultaneous heat and moisture transfer between the surface of the material and the surrounding media [8]. In order to preserve food quality during drying, various drying methods have been developed. For instance, in India, the arils are dried in the sun for 10 to 15 days and then sold as a spice [9]. Also, [10] investigated the use of freeze, convective and vacuum-microwave dryers for production of dried pomegranate arils and rind. The authors noted that significant reductions in the contents of sugars, organic acids, and total polyphenols associated with the drying process. Furthermore, [11] compared a thin layer drying behaviour of sour pomegranate arils using microwave, vacuum, and infrared methods, as well as convection drying. The authors reported that microwave pre-treatment combined with convective drying performed best for the drying of pomegranate arils taking into consideration the drying rate, effective moisture diffusion and activation energy.

However, several changes may occur in the food due to complex thermo-physical and biochemical processes that accompany the drying process. These changes affect the quality attributes of the end product [12]. Reports have shown that high temperature and long drying time affect food physical structures and chemical composition [13]. These changes include browning, shrinkage or loss of texture and a decrease in the bioactive composition of products. For example, according to Krokida [14], long drying times resulted in significant structural and colour changes in dehydrated apple, banana, carrot and potato. Further, Aguilera [15] reported that loss of nutrients during extensive food drying is inevitable. However, these changes could be reduced through pre-treating food materials prior to drying. The type of pre-treatments applied to food materials depends on the type of food to be dried and availability of pre-treatment [16]. Several pre-treatment methods applied to food materials have been studied to reduce the loss of colour due to enzyme activation, minimizing drying time and maintaining optimum nutritional qualities in the food samples [17]. Pre-treatment of food materials can be mechanical, such as soaking or dipping food materials in honey, heating either through steam or water blanching, or chemical application using treatment of materials with chemicals such as sulphur, ascorbic acid and sodium metabisulfite [16-18]. However, non-chemical pre-treatment (mechanical and heat) methods are preferable during food processing due to interference with sensory attributes of pre-treated products [19], elimination of off-flavours that may have been formed during postharvest, and removal of any residual pesticides [20,21]. Studies have shown blanching as a pre-treatment method that reduces drying time and preserves quality attributes of food products [22].

The analysis of the drying processes assists in validating appropriate operating conditions. Hence, understanding the temperature and moisture behavioural characteristics for the product is a necessity, especially for handling practices and quality control. Kinetic modelling is a useful approach to design and optimize thermal processes in order to maximise quality [23]. Several mathematical models have been employed for the purpose of moisture diffusion process in food products. Moisture diffusivity in solid food can be obtained in different forms, which changes in accordance with the geometry of the sample and the experimental conditions. These methods have been used to estimate moisture diffusivity and rely on drying kinetics, sorption, or desorption kinetics, as well as moisture profile analysis [24].

The mass transfer coefficient of food materials during drying was determined by Dincer and Hussain [25] to develop new Biot number and lag factor correlation. Mathematical models for pomegranate arils using a vacuum and microwave dryer was studied by Minaei et al. [8] and reported the validity of Midili and Page models. Lee and Kim [26] reported a tremendous change in effective diffusivity by studying the effect of drying temperature and material thickness of Asian white radish slices. Also, by studying the drying kinetics of pumpkin at different pressure and temperature levels, Arevalo-Pinedo and Fernando [27] reported that generated values of effective diffusivity for treated samples were smaller to calculated values. Similarly, by investigating the drying model for apples, 
Goyal et al. [28] reported that Logarithmic model best described the drying kinetics in comparison to other models investigated.

Several types of hot air drying have been implemented to dry agricultural crops, the design and operation of such dryers have been challenging due to the complexity of the parameters that govern the drying process and the factors affecting the quality of the product. One of the most important factors to be measured in dryer design is the drying rate for the prediction of drying time. Hence, investigating the appropriate model suitable for the modelling and prediction of the drying process is crucial. Since cultivar and nature of pre-treatment may affect the drying process, it is necessary to establish the appropriate drying model as a function of cultivar and pre-treatment. Therefore, the aims of this study were two-fold, first, to investigate the effect of different blanching conditions on thin-layer drying kinetics of three pomegranate cultivars, and second, to determine the mathematical model that best describes the characteristics of the drying process. In addition, effective diffusivity coefficients for the investigated cultivars were determined.

\section{Materials and Methods}

\subsection{Plant Material and Sample Processing}

Three pomegranate cultivars, "Acco", "Herskawitz" and "Wonderful", classified as sweet, sour and sweet-sour, respectively, were investigated. The fruit was harvested at commercial harvest $\left(13^{\circ}\right.$ Brix) between February and April in the 2018 harvest season from a local orchard in Wellington, South Africa ( $\left.33^{\circ} 01^{\prime} 00^{\prime \prime} \mathrm{S}, 18^{\circ} 58^{\prime} 59^{\prime \prime} \mathrm{E}\right)$. Fruit was sorted for uniformity in size, shape, and colour and transported in an air-conditioned vehicle to the Postharvest Technology Laboratory at Stellenbosch University. The arils were manually separated from the fruits and used for processing. Immediately before the blanching process, $10 \mathrm{~g}$ of pomegranate arils per cultivar were taken for initial moisture content determination $[9,29]$ with slight modification. The initial moisture content of the fresh arils was: $56.67 \%, 54.95 \%$ and $78.51 \%$ (w.b) for "Acco", "Herskawitz" and "Wonderful", respectively.

\subsection{Oven Drying Procedure}

Blanching of fresh arils was carried out in a water bath in batches. Samples were blanched at $90{ }^{\circ} \mathrm{C}$ and $100{ }^{\circ} \mathrm{C}$, each for $30 \mathrm{~s}$ and $60 \mathrm{~s}$. The unblanched sample was used as the control. Blanched arils were dipped in iced water $0^{\circ} \mathrm{C}$ for $3 \mathrm{~min}$ to halt the continuous heating process and carefully drained before weighing. The process was carried out in triplicates for each treatment. Samples $(60 \mathrm{~g})$ were weighed before being subjected to drying in an oven (Model nr. 072160, Prolab Instruments, Sep Sci., South Africa) set at a temperature of $60^{\circ} \mathrm{C}, 19.6 \%$ relative humidity and $1.0 \mathrm{~m} \mathrm{~s}^{-1}$ constant air velocity. The ambient air was used at $20 \pm 0.3{ }^{\circ} \mathrm{C}$ and $80 \%-88 \%$ RH. Weight loss was recorded every 60 min until the desired moisture content between $10 \% \pm 0.2 \%$, wet basis (w.b.) was reached [8,9] with slight modification. A schematic view of a laboratory hot-air convective drying system is illustrated in Figure 1. 


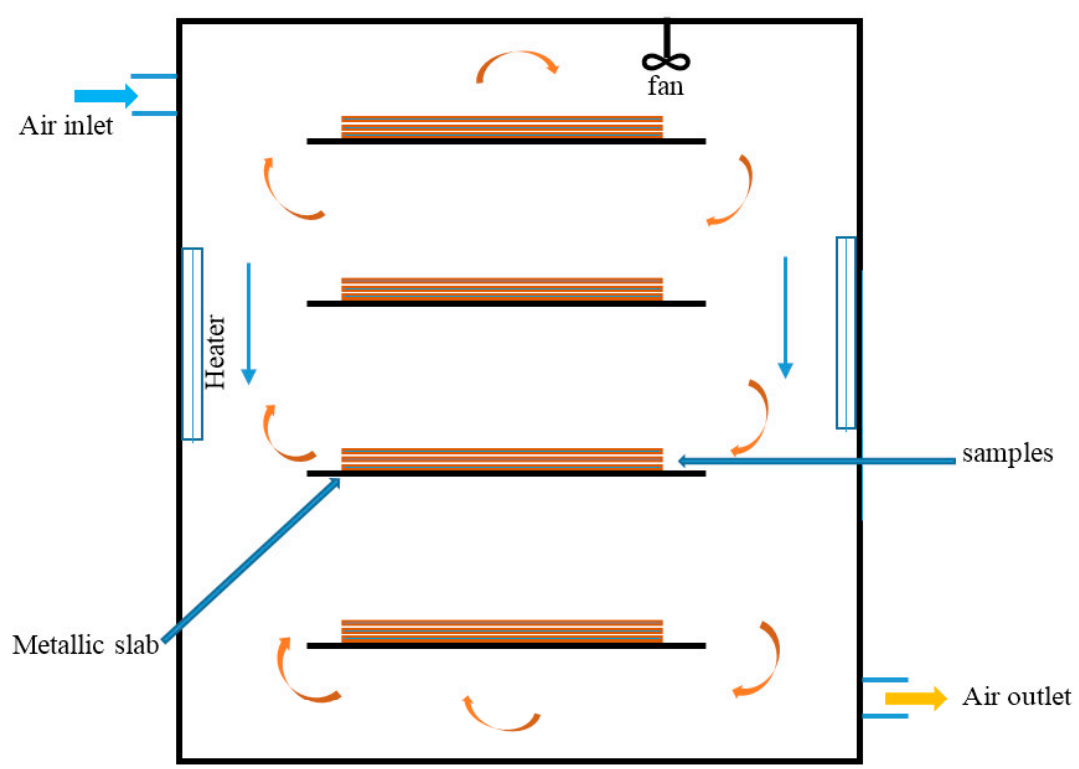

(a)

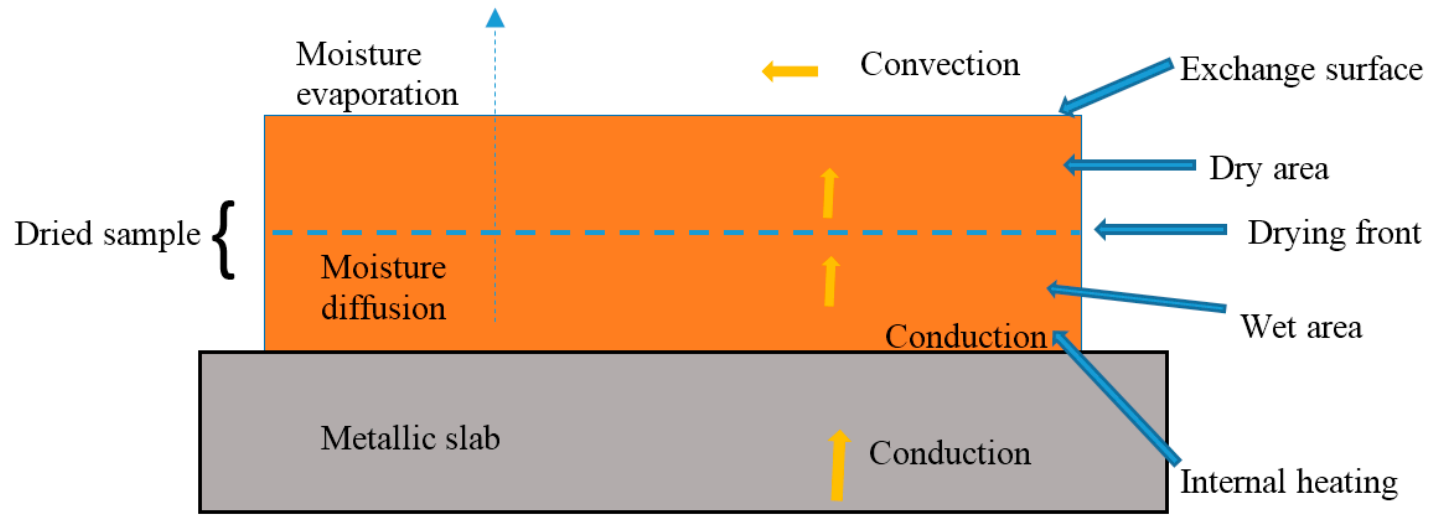

(b)

Figure 1. Experimental setup for the drying experiment. (a) Schematic diagram showing the laboratory hot-air convective drying system and (b) demonstrating the mechanism of heat and mass transfer through the sample.

\subsection{Mathematical Modelling}

To find the most suitable model, seven models were examined (Table 1). The selected mathematical models best describe drying mechanisms of food material and provide the required temperature and moisture information for proper control of the process [8].

Table 1. Empirical models describing blanched and unblanched pomegranate aril drying kinetics.

\begin{tabular}{cccc}
\hline Model & Name & Emperical Expression & References \\
\hline 1 & Lewis & $\mathrm{MR}=\exp (-k t)$ & {$[30]$} \\
2 & Henderson and Pabis & $\mathrm{MR}=\mathrm{a} \cdot \exp (-k t)$ & {$[30]$} \\
3 & Logarithmic & $\mathrm{MR}=\mathrm{a} \cdot \exp (-k t)+c$ & {$[31]$} \\
4 & Page & $\mathrm{MR}=\exp \left(-k t^{n}\right)$ & {$[32]$} \\
5 & Wang and Singh & $\mathrm{MR}=1+\mathrm{at}+\mathrm{bt}^{2}$ & {$[33]$} \\
6 & Modified Page & $\mathrm{MR}=\exp (-k t)^{n}$ & {$[30]$} \\
7 & Midili & $\mathrm{MR}=\mathrm{a} \cdot \exp \left(-k t^{n}\right)+\mathrm{bt}$ & {$[34]$} \\
\hline
\end{tabular}


In these models, the moisture ratio was simplified to Equation (1) according to [35]:

$$
M R=\frac{M_{t}}{M_{0}}
$$

where $M_{t}$ is the instantaneous moisture content at time $t(\mathrm{~h})$, and $M_{0}$ is the initial moisture content.

\subsection{Drying Rate (DR)}

The drying rate at a particular time was calculated by Sarpong et al. [36] in Equation (2):

$$
D R=\frac{M_{t 1}-M_{t 2}}{t_{2}-t_{1}}
$$

where $t_{1}$ and $t_{2}$ are the drying times (min) at different times during drying; $M_{t 1}$ and $M_{t 2}$ are the moisture content of samples $\left(\mathrm{g} \mathrm{min}{ }^{-1}\right)$.

\subsection{Effective Moisture Diffusivity Determination}

Fick's second law of diffusion is used to describe the drying process usually controlled by internal diffusion for most biological materials during the falling rate period [36] and shown in Equation (3):

$$
\frac{\delta M}{\delta t}=D_{e f f} \nabla^{2} M
$$

The effective moisture diffusivity $\left(D_{\text {eff }}\right)\left(\mathrm{m}^{2} \mathrm{~s}^{-1}\right)$ was calculated from the diffusion equation (Equation (3)) for the geometry on the assumption of unstable moisture diffusivity, spherical coordinate movement of moisture, constant temperature and diffusion coefficients and negligible shrinkage during the process of drying is given as the following [37]:

$$
M R=\frac{M_{t}}{M_{0}}=\frac{6}{\pi^{2}} \sum_{n=1}^{\infty} \frac{1}{n^{2}} \exp \left[-\frac{n^{2} \pi^{2} D_{e f f} t}{R^{2}}\right]
$$

where $D_{\text {eff }}$ is the effective moisture diffusivity $\left(\mathrm{m}^{2} \mathrm{~s}^{-1}\right), t$ is the time $(\mathrm{h}), R$ denotes the radius of the aril, assumed spherical and constant during the drying period, and $\mathrm{n}$ is a positive integer. In the case of longer drying periods, the above equation can be simplified to the only first term of series, without much affecting the accuracy of the prediction $[8,37,38]$ :

$$
\operatorname{In}(M R)=\operatorname{In} \frac{6}{\pi^{2}}-\left(-\frac{\pi^{2} D_{e f f} t}{R^{2}}\right)
$$

From Equation (5), a plot of $\ln (M R)$ versus drying time gives a straight line with a slope $(K)$ of:

$$
K=\frac{\pi^{2} D_{e f f}}{R^{2}}
$$

\subsection{Statistical Analysis of the Models}

Data was processed with STATISTICA (Statistica 13.0, StatSoft Inc., Tulsa, OK, USA) and presented as means \pm standard error. All analysis was done in triplicate. Factorial analysis of variance (ANOVA) in order to observe if the mean values were statistically different and the Fisher's LSD test at a level of significance of $95 \%$. The moisture ratio curves obtained were fitted with seven mathematical models in order to describe the drying characteristics of blanched and unblanched pomegranate arils. Multiple regression analysis was performed using MATLAB software. The experimental data were evaluated 
with the coefficient of determination $\left(R^{2}\right)$ and the root mean square error (RMSE). The higher the $R^{2}$ values, and the lower the RMSE values, the better the model of best fit [30].

$$
\begin{gathered}
R^{2}=\frac{\sum_{i-1}^{N}\left(M R_{i}-M R_{\text {pre }, i}\right) \cdot \sum_{i=1}^{N}\left(M R_{i}-M R_{\text {exp }, i}\right)}{\sqrt{\sum_{i=1}^{N}\left(M R_{i}-M R_{\text {pre }, i}\right)^{2}} \cdot \sum_{i=1}^{N}\left(M R_{i}-M R_{\text {exp. } i}\right)^{2}} \\
R M S E=\sqrt{\frac{1}{N}} \sum_{i=1}^{N}\left(M R_{\text {pre }, i}-M R_{\text {exp }, i}\right)^{2}
\end{gathered}
$$

$M R_{\text {exp }, i}$ is the $i$ th experimentally determined moisture ratio, $M R_{p r e, i}$ is the $i$ th predicted moisture ratio value, $N$ is the number of observations and $\mathrm{z}$, the number of drying constants.

\section{Results and Discussion}

\subsection{Effect of Blanching Conditions on Drying Kinetics of Dried Pomegranate Aril}

\subsubsection{Moisture Ratio}

Figure 2 shows a pictorial representation of the trend of pomegranate arils before and after processing. At the end of drying, blanched samples became stickier while the unblanched appeared easily separated from each other, which informs part of the textural properties during crushing and grinding [39].

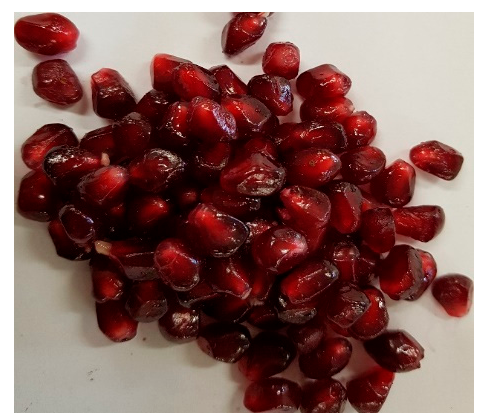

(a)

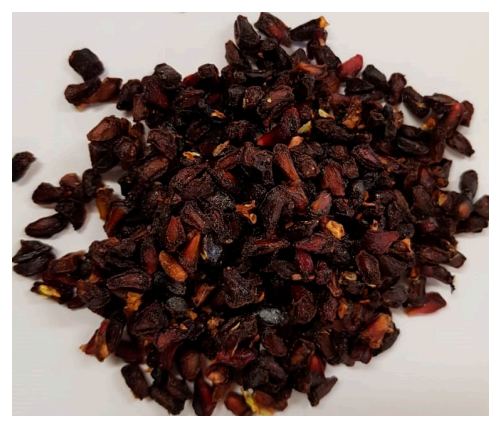

(b)

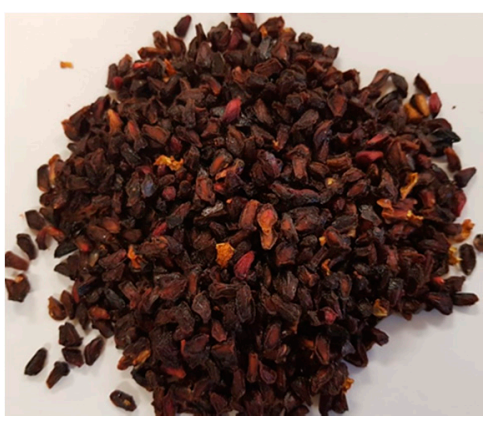

(c)

Figure 2. Pomegranate arils at different stages (a) samples before processing, (b) blanch-assisted dried arils and (c) unblanched dried arils (control).

Also, blanched samples showed glistering dark-purple colour as a result of the occurrence of Maillard reactions during drying [40], while unblanched arils appeared pale. Amongst the investigated cultivars, the order of average drying time blanched sample $\left(100{ }^{\circ} \mathrm{C}\right.$ for $\left.60 \mathrm{~s}\right)$ and unblanched sample (control) was observed in the order of cultivar "Herskawitz" (600 min) > "Acco" (420 min) > "Wonderful" (300 min) regardless of blanching condition (Figure 3).

Moisture ratio (MR) decreased rapidly with drying time for "Acco", "Herskawitz" and "Wonderful" dried pomegranate arils. The drying curves showed the same trend regardless of blanching conditions. For instance, moisture content decreased, and the desired moisture was reached faster in blanched samples (420-480 $\mathrm{min}$ ) than in the unblanched (660-1200 $\mathrm{min})$, regardless of blanching condition (Figure 4). This amounted to approximately 53\%, 60\% and 36\% reduction in drying time for "Acco", "Herskawitz" and "Wonderful", respectively. 


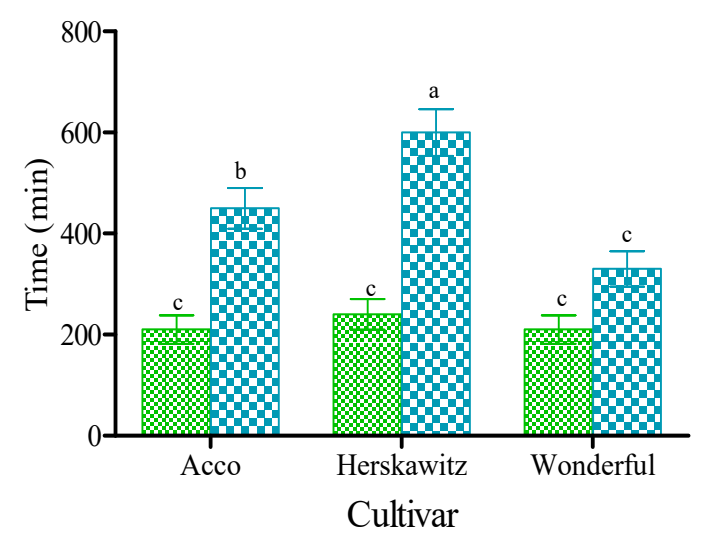

\section{Blanched \\ B8 Unblanched}

Figure 3. Drying time (min) of arils extracted from pomegranate cultivars (Acco, Herskawitz and Wonderful), blanched at $100^{\circ} \mathrm{C}$ for $60 \mathrm{~s}$ and dried in a hot-air flow rate of $1 \mathrm{~m} \mathrm{~s}^{-1}$ at $60^{\circ} \mathrm{C}$ and $19.6 \% \mathrm{RH}$.
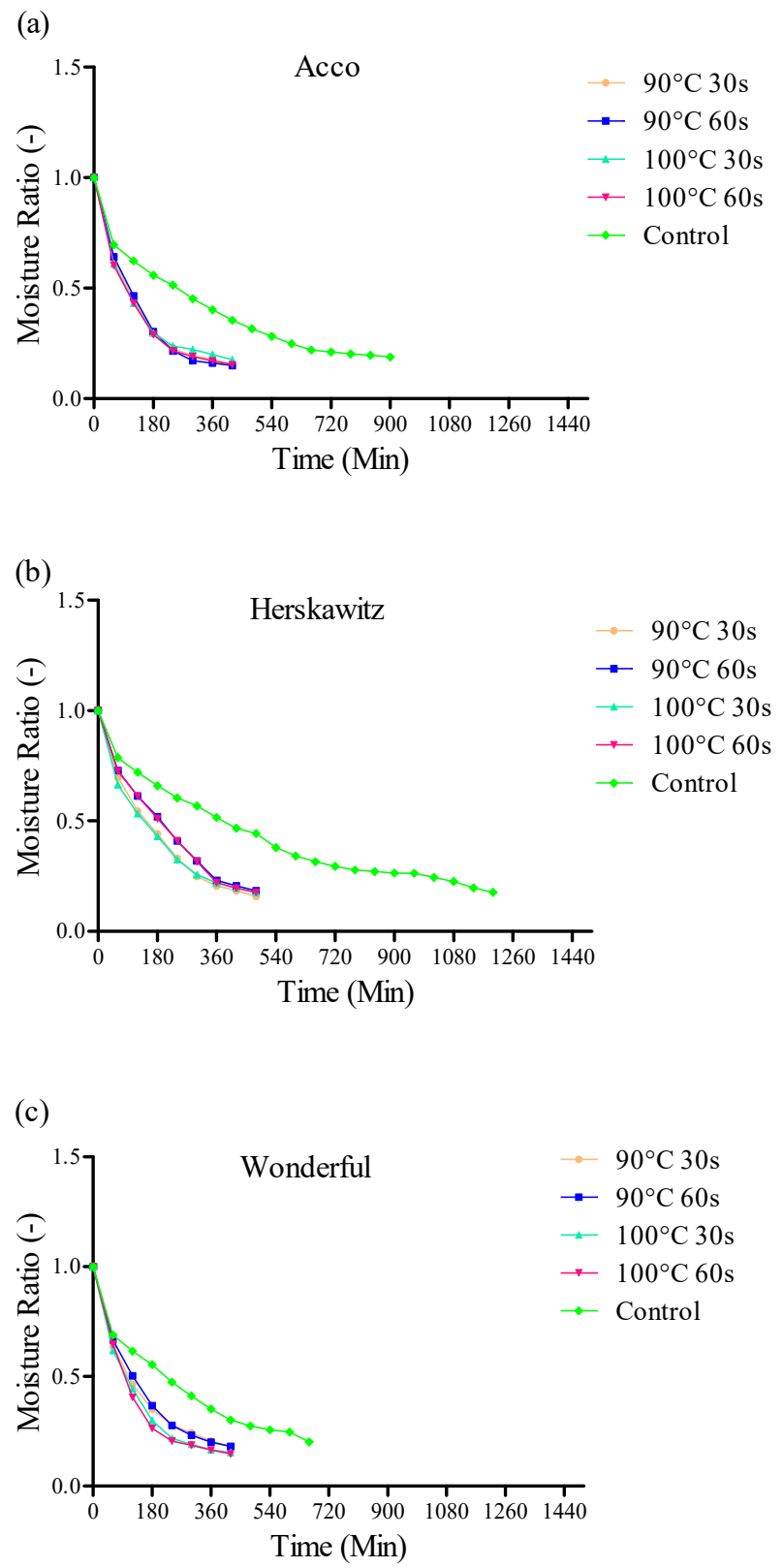

Figure 4. Drying curves for pomegranate aril cultivars (a) Acco, (b) Herskawitz and (c) Wonderful at a hot-air flow rate of $1 \mathrm{~m} \mathrm{~s}^{-1}$, temperature condition $60{ }^{\circ} \mathrm{C}$ and $19.6 \% \mathrm{RH}$. 


\subsubsection{Drying Rate}

The variation in drying rate with drying time obtained from Equation (2) is shown in Figure 5 for "Acco", "Herskawitz" and "Wonderful", respectively.
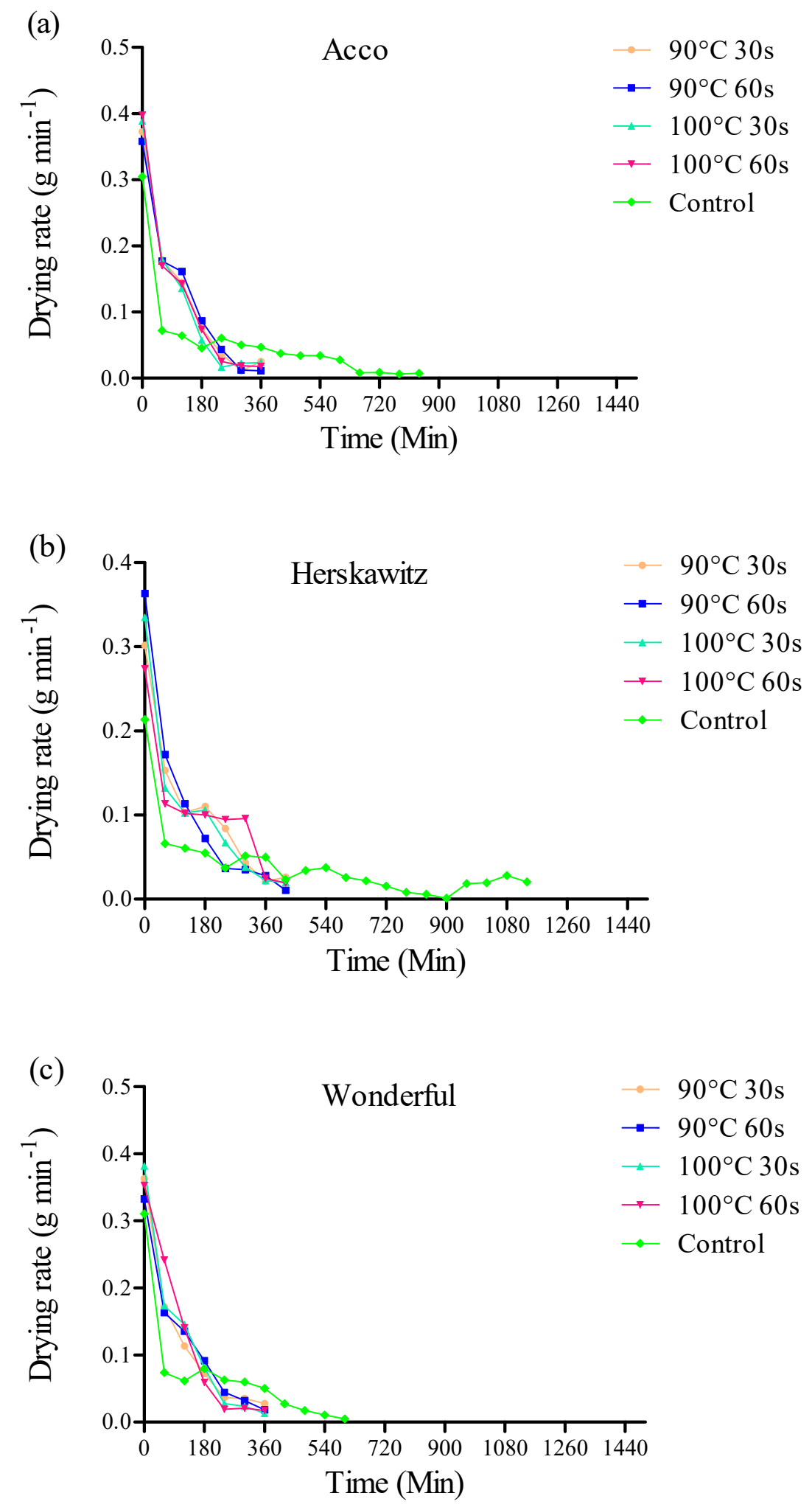

Figure 5. Drying rate versus drying time of pomegranate arils for cultivars (a) Acco, (b) Herskawitz and (c) Wonderful at hot-air flow rate of $1 \mathrm{~m} \mathrm{~s}^{-1}$, temperature condition $60{ }^{\circ} \mathrm{C}$ and $19.6 \% \mathrm{RH}$. 
In the early stages, drying rate increased rapidly, reaching a maximum value, then a progressive decrease with drying time was observed. Drying rates for both blanched and unblanched samples followed a pattern of falling rate period, which is considered as a phenomenon of diffusion-control. A similar trend was observed in the studies by Minaei et al. [8] for pomegranate arils; Wang et al. [30] and Kaya et al. [41] in apples. During the falling rate period, the highest drying rates were found in the blanched samples ranging from $\left(0.358\right.$ to $0.398 \mathrm{~g} \mathrm{~min}^{-1} ; 0.274$ to $0.363 \mathrm{~g} \mathrm{~min}^{-1}$ and 0.333 to $0.382 \mathrm{~g}$ $\mathrm{min}^{-1}$ ) for "Acco", "Herskawitz" and "Wonderful", respectively, while all unblanched samples had the lowest drying rate (ranging from 0.214 to $0.311 \mathrm{~g} \mathrm{~min}^{-1}$ ) for the three cultivars. The rates of drying for all blanched arils were higher than the unblanched pomegranate arils for "Acco", "Herskawitz" and "Wonderful". Also, the differences in drying were highest at the early stage of drying when the greater amount of water in the sample is evaporated and at the later stage, the differences in the amount of moisture evaporation in the sample is gradually lower (Figure 5). The higher drying rate is ascribed to the microstructural differences between the blanched and unblanched pomegranate arils. Microstructural differences between fresh apple pomace and the pre-treated apple pomace were reported by Wang et al. [30]. This is due to the porous structure and shrinkage of arils during blanching as a result of wide spaces between neighbouring cells [42,43].

\subsubsection{Moisture Diffusion}

An isothermal temperature at $60^{\circ} \mathrm{C}$ was maintained during the drying process. There were variations in Deff for all the blanching conditions regardless of the cultivars Table 2.

Table 2. Moisture effective diffusion (Deff) of dried pomegranate aril under different blanching conditions for different cultivars.

\begin{tabular}{|c|c|c|}
\hline Cultivar/Classification & Blanching Condition & Moisture Diffusivity $\left(\mathrm{m}^{2} / \mathrm{s}\right)$ \\
\hline \multirow[t]{5}{*}{ Acco } & Control & $4.81 \times 10^{-9}$ \\
\hline & $90^{\circ} \mathrm{C} 30 \mathrm{~s}$ & $1.24 \times 10^{-8}$ \\
\hline & $90^{\circ} \mathrm{C} 60 \mathrm{~s}$ & $1.34 \times 10^{-8}$ \\
\hline & $100^{\circ} \mathrm{C} 30 \mathrm{~s}$ & $1.11 \times 10^{-8}$ \\
\hline & $100^{\circ} \mathrm{C} 60 \mathrm{~s}$ & $1.24 \times 10^{-8}$ \\
\hline \multirow[t]{5}{*}{ Herskawitz } & Control & $3.29 \times 10^{-9}$ \\
\hline & $90^{\circ} \mathrm{C} 30 \mathrm{~s}$ & $1.04 \times 10^{-8}$ \\
\hline & $90^{\circ} \mathrm{C} 60 \mathrm{~s}$ & $1.19 \times 10^{-8}$ \\
\hline & $100{ }^{\circ} \mathrm{C} 30 \mathrm{~s}$ & $1.11 \times 10^{-8}$ \\
\hline & $100{ }^{\circ} \mathrm{C} 60 \mathrm{~s}$ & $1.01 \times 10^{-8}$ \\
\hline \multirow[t]{5}{*}{ Wonderful } & Control & $5.83 \times 10^{-9}$ \\
\hline & $90^{\circ} \mathrm{C} 30 \mathrm{~s}$ & $1.09 \times 10^{-8}$ \\
\hline & $90^{\circ} \mathrm{C} 60 \mathrm{~s}$ & $1.14 \times 10^{-8}$ \\
\hline & $100{ }^{\circ} \mathrm{C} 30 \mathrm{~s}$ & $1.27 \times 10^{-8}$ \\
\hline & $100{ }^{\circ} \mathrm{C} 60 \mathrm{~s}$ & $1.29 \times 10^{-8}$ \\
\hline
\end{tabular}

Deff values were within the range of $4.81 \times 10^{-9}$ and $1.11 \times 10^{-8} \mathrm{~m}^{2} \mathrm{~s}^{-1}$ for the Acco cultivar, for the Herskawitz cultivar; $3.29 \times 10^{-9}$ and $1.01 \times 10^{-8} \mathrm{~m}^{2} \mathrm{~s}^{-1}$ and for the Wonderful cultivar; $5.83 \times$ $10^{-9}$ and $1.09 \times 10^{-8} \mathrm{~m}^{2} \mathrm{~s}^{-1}$. The highest Deff was recorded for samples blanched at $90{ }^{\circ} \mathrm{C}$ for $60 \mathrm{~s}$ for Acco and Herskawitz cultivars, while $\left(100{ }^{\circ} \mathrm{C}\right.$ for $\left.60 \mathrm{~s}\right)$ for the Wonderful cultivar. However, control samples for all cultivars had the lowest Deff values.

As observed in Figure 4, blanching condition lowered drying time. These results suggested the positive impact of blanching by lowering the drying time of pomegranate arils, regardless of the cultivar. Results from this study correspond with findings by Karaaslan et al. [29], who reported the shortest drying time for pre-treated samples of pomegranate aril under vacuum dryer. A 20\% reduction in drying time for banana under a relative humidity-convective air dryer was also reported by Sarpong et al. [36]. Variability in blanching conditions with a similar drying curve indicated that increased temperature or duration during blanching had no distinct differences on the drying kinetics 
of dried pomegranate arils. This result also agreed with the study by Sarpong et al. [36], who reported no significant effect on the drying kinetics of dried banana as a result of similar drying curves for all treatments.

Moisture diffusion and drying rate phenomena are dependent on temperature and product composition [8]. It is thus logical to attribute the observed differences in moisture diffusion and drying time to initial moisture content in the investigated Acco (56.67\%), Herskawitz (54.95\%) and Wonderful $(78.51 \%)$ pomegranate cultivars. Generally, higher values were found in the blanched samples, which is connected to the rapid removal of moisture and faster drying of the samples. Deff values reported in this study were close to the range previously reported for pomegranate arils, with Deff values of $0.74 \times 10^{-10}$ to $5.25 \times 10^{-10} \mathrm{~m}^{2} \mathrm{~s}^{-1}$ and $3.05 \times 10^{-10}$ to $3.43 \times 10^{-10} \mathrm{~m}^{2} \mathrm{~s}^{-1}$ for vacuum and microwave dried arils, respectively [8]. High Deff values among the blanching conditions indicated that moisture movement in pomegranate arils was in liquid form, a notion reported by Sarpong et al. [36] for banana slices.

\subsection{Fitting of Drying Curve}

The $R^{2}$ and RMSE were used to determine the goodness of fit model as shown in Tables 3-5. 
Table 3. Curve fitting criteria for various mathematical models and parameters for blanched and unblanched pomegranate arils cv. Acco.

\begin{tabular}{|c|c|c|c|c|c|c|c|}
\hline Model Number & $k$ & $a$ & $b$ & $c$ & $n$ & Determining Coefficient $\left(R^{2}\right)$ & Root Mean Square Error (RMSE) \\
\hline \multicolumn{8}{|c|}{$90{ }^{\circ} \mathrm{C} 30 \mathrm{~s}$} \\
\hline 1 & $1.01 \times 10^{-4}$ & & & & & 0.9821 & 0.017932 \\
\hline 2 & $9.63 \times 10^{-5}$ & 0.9550 & & & & 0.9779 & 0.015464 \\
\hline 3 & $1.49 \times 10^{-4}$ & 0.8611 & & 0.1365 & & 0.9989 & 0.000686 \\
\hline 4 & $1.02 \times 10^{-3}$ & & & & 0.7371 & 0.9949 & 0.02257 \\
\hline 5 & & $-8.75 \times 10^{-5}$ & $2.22 \times 10^{-9}$ & & & 0.9804 & 0.01557 \\
\hline 6 & $1.08 \times 10^{-5}$ & & & & 9.3788 & 0.9821 & 0.017933 \\
\hline 7 & $1.59 \times 10^{-3}$ & 1.01107 & $9.30 \times 10^{-7}$ & & 0.7097 & 0.9949 & 0.003182 \\
\hline \multicolumn{8}{|c|}{$90^{\circ} \mathrm{C} 60 \mathrm{~s}$} \\
\hline 1 & 0.00010 & & & & & 0.9880 & 0.011722 \\
\hline 2 & $9.91 \times 10^{-5}$ & 0.9687 & & & & 0.9857 & 0.010517 \\
\hline 3 & 0.000138 & 0.8899 & & 0.1101 & & 0.9979 & 0.001314 \\
\hline 4 & 0.00064 & & & & 0.8036 & 0.9940 & 0.003859 \\
\hline 5 & & $-8.75 \times 10^{-5}$ & $2.22 \times 10^{-9}$ & & & 0.9877 & 0.010128 \\
\hline 6 & $1.09 \times 10^{-5}$ & & & & 9.4298 & 0.9880 & 0.011722 \\
\hline 7 & 0.00159 & 1.0111 & $9.3 \times 10^{-7}$ & & 0.7097 & 0.9905 & 0.007004 \\
\hline \multicolumn{8}{|c|}{$100^{\circ} \mathrm{C} 30 \mathrm{~s}$} \\
\hline 1 & 0.00010 & & & & & 0.9682 & 0.031770 \\
\hline 2 & $9.3 \times 10^{-5}$ & 0.9550 & & & & 0.9628 & 0.027411 \\
\hline 3 & 0.00015 & 0.8611 & & 0.1365 & & 0.9966 & 0.002839 \\
\hline 4 & 0.00118 & & & & 0.7371 & 0.9914 & 0.006068 \\
\hline 5 & & $-8.75 \times 10^{-5}$ & $2.22 \times 10^{-9}$ & & & 0.9691 & 0.024845 \\
\hline 6 & $1.09 \times 10^{-5}$ & & & & 9.4298 & 0.9694 & 0.032035 \\
\hline 7 & 0.00159 & 1.0111 & $9.3 \times 10^{-7}$ & & 0.7097 & 0.9947 & 0.003418 \\
\hline \multicolumn{8}{|c|}{$100^{\circ} \mathrm{C} 60 \mathrm{~s}$} \\
\hline 1 & 0.00010 & & & & & 0.9753 & 0.022735 \\
\hline 2 & $9.9 \times 10^{-5}$ & 0.8987 & & & & 0.9721 & 0.023406 \\
\hline 3 & 0.00015 & 0.8611 & & 0.1365 & & 0.9977 & 0.002243 \\
\hline 4 & 0.00118 & & & & 0.7371 & 0.9938 & 0.004394 \\
\hline 5 & & $-8.8 \times 10^{-5}$ & $2.22 \times 10^{-9}$ & & & 0.9749 & 0.021579 \\
\hline 6 & $1.08 \times 10^{-5}$ & & & & 9.9287 & 0.9794 & 0.022169 \\
\hline 7 & 0.00159 & 1.0111 & $9.30 \times 10^{-7}$ & & 0.7097 & 0.9958 & 0.003968 \\
\hline
\end{tabular}


Table 3. Cont.

\begin{tabular}{|c|c|c|c|c|c|c|}
\hline Model Number & $k$ & $a$ & $b$ & $n$ & Determining Coefficient $\left(R^{2}\right)$ & Root Mean Square Error (RMSE) \\
\hline \multicolumn{7}{|c|}{ Control } \\
\hline 1 & $3.97 \times 10^{-5}$ & & & & 0.9525 & 0.094019 \\
\hline 2 & $3.22 \times 10^{-5}$ & 0.8519 & & & 0.9353 & 0.047809 \\
\hline 3 & $2.68 \times 10^{-5}$ & 0.7439 & & 0.2561 & 0.9871 & 0.009322 \\
\hline 4 & 0.00249 & & & 0.5933 & 0.9918 & 0.005697 \\
\hline 5 & & $-3.50 \times 10^{-5}$ & $3.90 \times 10^{-10}$ & & 0.9599 & 0.075367 \\
\hline 6 & $9.98 \times 10^{-6}$ & & & 3.99 & 0.9527 & 0.094028 \\
\hline 7 & 0.00185 & 0.99412 & $4.33 \times 10^{-7}$ & 0.6254 & 0.9920 & 0.005833 \\
\hline
\end{tabular}

Table 4. Curve fitting criteria for various mathematical models and parameters for blanched and unblanched pomegranate arils cv. Herskawitz.

\begin{tabular}{|c|c|c|c|c|c|c|c|}
\hline Model Number & $k$ & $a$ & $b$ & $c$ & $n$ & Determining Coefficient $\left(R^{2}\right)$ & Root Mean Square Error (RMSE) \\
\hline \multicolumn{8}{|c|}{$90{ }^{\circ} \mathrm{C} 30 \mathrm{~s}$} \\
\hline 1 & $7.61 \times 10^{-5}$ & & & & & 0.9821 & 0.017932 \\
\hline 2 & $7.27 \times 10^{-5}$ & 0.9611 & & & & 0.9779 & 0.015464 \\
\hline 3 & 0.00011 & 0.8611 & & 0.1365 & & 0.9989 & 0.000686 \\
\hline 4 & 0.001 & & & & 0.7371 & 0.9949 & 0.02257 \\
\hline 5 & & $-8.75 \times 10^{-5}$ & $2.22 \times 10^{-9}$ & & & 0.9804 & 0.01557 \\
\hline 6 & $9.17 \times 10^{-6}$ & & & & 8.2998 & 0.9821 & 0.017933 \\
\hline 7 & 0.00129 & 1.0211 & $9.30 \times 10^{-7}$ & & 0.7097 & 0.9949 & 0.003182 \\
\hline \multicolumn{8}{|c|}{$90^{\circ} \mathrm{C} 60 \mathrm{~s}$} \\
\hline 1 & $6.42 \times 10^{-5}$ & & & & & 0.9880 & 0.011722 \\
\hline 2 & $6.33 \times 10^{-5}$ & 0.9750 & & & & 0.9857 & 0.010517 \\
\hline 3 & 0.000109 & 0.8711 & & 0.1765 & & 0.9979 & 0.001314 \\
\hline 4 & 0.00018 & & & & 0.8916 & 0.9940 & 0.003859 \\
\hline 5 & & $-8.35 \times 10^{-5}$ & $2.22 \times 10^{-9}$ & & & 0.9877 & 0.010128 \\
\hline 6 & $8.43 \times 10^{-6}$ & & & & 7.6155 & 0.9880 & 0.011722 \\
\hline 7 & 0.00109 & 1.0111 & $9.2 \times 10^{-7}$ & & 0.7097 & 0.9905 & 0.007004 \\
\hline
\end{tabular}


Table 4. Cont.

\begin{tabular}{|c|c|c|c|c|c|c|}
\hline Model Number & $k$ & $a$ & $b$ & $n$ & Determining Coefficient $\left(R^{2}\right)$ & Root Mean Square Error (RMSE) \\
\hline \multicolumn{7}{|c|}{$100^{\circ} \mathrm{C} 30 \mathrm{~s}$} \\
\hline 1 & $7.63 \times 10^{-5}$ & & & & 0.9682 & 0.031770 \\
\hline 2 & $7.33 \times 10^{-5}$ & 0.9550 & & & 0.9628 & 0.027411 \\
\hline 3 & 0.00011 & 0.8011 & & 0.1565 & 0.9966 & 0.002839 \\
\hline 4 & 0.0002 & & & 0.8991 & 0.9914 & 0.006068 \\
\hline 5 & & $-8.40 \times 10^{-5}$ & $2.22 \times 10^{-9}$ & & 0.9691 & 0.024845 \\
\hline 6 & $9.19 \times 10^{-6}$ & & & 8.3037 & 0.9694 & 0.032035 \\
\hline 7 & 0.00119 & 1.0011 & $9.0 \times 10^{-7}$ & 0.7097 & 0.9947 & 0.003418 \\
\hline \multicolumn{7}{|c|}{$100^{\circ} \mathrm{C} 60 \mathrm{~s}$} \\
\hline 1 & $6.53 \times 10^{-5}$ & & & & 0.9753 & 0.022735 \\
\hline 2 & $6.53 \times 10^{-5}$ & 0.9650 & & & 0.9721 & 0.023406 \\
\hline 3 & $6.75 \times 10^{-5}$ & 0.9482 & & 0.0295 & 0.9977 & 0.002243 \\
\hline 4 & 0.00016 & & & 0.9048 & 0.9938 & 0.004394 \\
\hline 5 & & $-9.0 \times 10^{-5}$ & $2.22 \times 10^{-9}$ & & 0.9749 & 0.021579 \\
\hline 6 & $7.82 \times 10^{-6}$ & & & 8.3567 & 0.9794 & 0.022169 \\
\hline 7 & 0.00129 & 1.0011 & $2.21 \times 10^{-6}$ & 0.7097 & 0.9958 & 0.003968 \\
\hline \multicolumn{7}{|c|}{ Control } \\
\hline 1 & $2.96 \times 10^{-5}$ & & & & 0.9525 & 0.094019 \\
\hline 2 & $3.22 \times 10^{-5}$ & 0.9819 & & & 0.9353 & 0.047809 \\
\hline 3 & $1.29 \times 10^{-4}$ & 0.9611 & & 0.2665 & 0.9871 & 0.009322 \\
\hline 4 & 0.00209 & & & 0.5933 & 0.9918 & 0.005697 \\
\hline 5 & & $-3.50 \times 10^{-5}$ & $3.90 \times 10^{-10}$ & & 0.9599 & 0.075367 \\
\hline 6 & $9.98 \times 10^{-6}$ & & & 2.99 & 0.9527 & 0.094028 \\
\hline 7 & 0.00145 & 0.99412 & $5.33 \times 10^{-7}$ & 0.6254 & 0.9920 & 0.005833 \\
\hline
\end{tabular}

1 Lewis, 2 Henderson and Pabis, 3 Logarithmic, 4 Page, 5 Wang and Singh, 6 Modified Page, 7 Midili. 
Table 5. Curve fitting criteria for various mathematical models and parameters for blanched and unblanched pomegranate arils cv. Wonderful.

\begin{tabular}{|c|c|c|c|c|c|c|c|}
\hline Model Number & $k$ & $a$ & $b$ & $c$ & $n$ & Determining Coefficient $\left(R^{2}\right)$ & Root Mean Square Error (RMSE) \\
\hline \multicolumn{8}{|c|}{$90{ }^{\circ} \mathrm{C} 30 \mathrm{~s}$} \\
\hline 1 & $1.02 \times 10^{-4}$ & & & & & 0.9821 & 0.017932 \\
\hline 2 & $9.33 \times 10^{-5}$ & 0.9880 & & & & 0.9779 & 0.015464 \\
\hline 3 & $1.19 \times 10^{-4}$ & 0.8611 & & 0.1365 & & 0.9989 & 0.000686 \\
\hline 4 & $1.07 \times 10^{-3}$ & & & & 0.7371 & 0.9949 & 0.02257 \\
\hline 5 & & $-8.75 \times 10^{-5}$ & $2.22 \times 10^{-9}$ & & & 0.9804 & 0.01557 \\
\hline 6 & $1.01 \times 10^{-5}$ & & & & 9.1787 & 0.9821 & 0.017933 \\
\hline 7 & $1.39 \times 10^{-3}$ & 1.01107 & $9.30 \times 10^{-7}$ & & 0.7097 & 0.9949 & 0.003182 \\
\hline \multicolumn{8}{|c|}{$90^{\circ} \mathrm{C} 60 \mathrm{~s}$} \\
\hline 1 & $1.01 \times 10^{-4}$ & & & & & 0.9880 & 0.011722 \\
\hline 2 & $9.95 \times 10^{-5}$ & 0.9999 & & & & 0.9857 & 0.010517 \\
\hline 3 & $1.18 \times 10^{-4}$ & 0.8899 & & 0.1101 & & 0.9979 & 0.001314 \\
\hline 4 & $5.2 \times 10^{-4}$ & & & & 0.8046 & 0.9940 & 0.003859 \\
\hline 5 & & $-8.75 \times 10^{-5}$ & $2.22 \times 10^{-9}$ & & & 0.9877 & 0.010128 \\
\hline 6 & $1.00 \times 10^{-5}$ & & & & 9.0898 & 0.9880 & 0.011722 \\
\hline 7 & 0.00139 & 1.0011 & $9.3 \times 10^{-7}$ & & 0.7097 & 0.9905 & 0.007004 \\
\hline \multicolumn{8}{|c|}{$100^{\circ} \mathrm{C} 30 \mathrm{~s}$} \\
\hline 1 & 0.00010 & & & & & 0.9682 & 0.031770 \\
\hline 2 & $9.97 \times 10^{-5}$ & 0.9850 & & & & 0.9628 & 0.027411 \\
\hline 3 & $1.49 \times 10^{-4}$ & 0.8611 & & 0.1365 & & 0.9966 & 0.002839 \\
\hline 4 & 0.00118 & & & & 0.7371 & 0.9914 & 0.006068 \\
\hline 5 & & $-8.75 \times 10^{-5}$ & $2.22 \times 10^{-9}$ & & & 0.9691 & 0.024845 \\
\hline 6 & $1.08 \times 10^{-5}$ & & & & 9.5787 & 0.9694 & 0.032035 \\
\hline 7 & 0.00159 & 1.0111 & $9.3 \times 10^{-7}$ & & 0.7097 & 0.9947 & 0.003418 \\
\hline
\end{tabular}


Table 5. Cont

\begin{tabular}{|c|c|c|c|c|c|c|c|}
\hline Model Number & $k$ & $a$ & $b$ & $c$ & $n$ & Determining Coefficient $\left(R^{2}\right)$ & Root Mean Square Error (RMSE) \\
\hline \multicolumn{8}{|c|}{$100{ }^{\circ} \mathrm{C} 60 \mathrm{~s}$} \\
\hline 1 & $1.01 \times 10^{-4}$ & & & & & 0.9753 & 0.022735 \\
\hline 2 & $9.96 \times 10^{-5}$ & 0.9720 & & & & 0.9721 & 0.023406 \\
\hline 3 & $1.49 \times 10^{-4}$ & 0.8611 & & 0.1265 & & 0.9977 & 0.002243 \\
\hline 4 & 0.00138 & & & & 0.7271 & 0.9938 & 0.004394 \\
\hline 5 & & $-8.85 \times 10^{-5}$ & $2.22 \times 10^{-9}$ & & & 0.9749 & 0.021579 \\
\hline 6 & $1.08 \times 10^{-5}$ & & & & 9.7987 & 0.9794 & 0.022169 \\
\hline 7 & 0.00169 & 1.0111 & $9.30 \times 10^{-7}$ & & 0.7097 & 0.9958 & 0.003968 \\
\hline \multicolumn{8}{|c|}{ Control } \\
\hline 1 & $4.97 \times 10^{-5}$ & & & & & 0.9525 & 0.094019 \\
\hline 2 & $3.52 \times 10^{-5}$ & 0.7506 & & & & 0.9353 & 0.047809 \\
\hline 3 & $9.99 \times 10^{-5}$ & 0.7439 & & 0.2561 & & 0.9871 & 0.009322 \\
\hline 4 & 0.00279 & & & & 0.5933 & 0.9918 & 0.005833 \\
\hline 5 & & $-3.50 \times 10^{-5}$ & $3.90 \times 10^{-10}$ & & & 0.9599 & 0.075367 \\
\hline 6 & $9.98 \times 10^{-6}$ & & & & 4.99 & 0.9527 & 0.094028 \\
\hline 7 & 0.00185 & 0.94412 & $4.33 \times 10^{-7}$ & & 0.6254 & 0.9920 & 0.005697 \\
\hline
\end{tabular}

1 Lewis, 2 Henderson and Pabis, 3 Logarithmic, 4 Page, 5 Wang and Singh, 6 Modified Page, 7 Midili. 
For the Acco cultivar, the Logarithmic model gave the highest $R^{2}$ value for all blanched samples which varied from 0.9966 to 0.9989 , while for the Page model, for unblanched samples value was 0.9918 (Table 3). Furthermore, the values of RMSE for the Logarithmic model in the Acco cultivar varied from 0.000686 to 0.002839 for blanched samples, while the value was 0.005697 for the page model for unblanched samples (Table 3). For the Herskawitz cultivar, the highest $R^{2}$ values were observed in Logarithmic, Page and Midili models for blanched samples varying from 0.9932 to 0.9973 , while the Midili model had the highest $R^{2}$ value for unblanched samples (0.9844) Table 4. Also, the values of RMSE for the Logarithmic, Page and Midili models varied from 0.003201 to 0.004340 for blanched samples, while the value was 0.005697 for Page model for unblanched samples (Table 4). Similarly, for the Wonderful cultivar, the highest $R^{2}$ values were observed in the Logarithmic and Midili models for blanched samples, which varied from 0.9972 to 0.9988 whereas, for unblanched samples, the Midili model had the highest $R^{2}$ value $(0.9929$, Table 5). Consequently, the RMSE values for the Logarithmic and Midili models for blanched samples varied from 0.001128 to 0.002370 for blanched samples while the value was 0.005697 for Midili model for unblanched samples (Table 5).

From the tables, it was observed that Logarithmic, Page and Midili amongst other models considered for best fit represented the drying characteristics of both blanched and unblanched pomegranate arils for each analysis based on blanching condition and cultivar. The suitability of Logarithmic, Page and Midili models described the observed conformity between $R^{2}$ and RMSE values according to Wang et al. [30], the higher the $R^{2}$ values and the lower the RMSE values, the better the model of best fit. This is also similar to the observations reported for drying of pre-treated and untreated pumpkin [44].

\section{Conclusions}

The effect of blanching on the drying of "Acco", "Herskawitz" and "Wonderful" pomegranate arils in a hot-air dryer was investigated. The blanched samples dried faster with a shorter drying time: "Acco" (7 h), "Herskawitz" (8 h) and "Wonderful" (7 h), compared to the unblanched samples which dried after 15, 20 and $11 \mathrm{~h}$, respectively. The trend of blanching showed a falling rate as observed against time. Blanched samples had a higher drying rate than the unblanched samples. The lowest moisture diffusion was obtained as $4.81 \times 10^{-9}, 3.29 \times 10^{-9}$ and $5.83 \times 10^{-9} \mathrm{~m}^{2} \mathrm{~s}^{-1}$ for Acco, Herskawitz and Wonderful cultivars, respectively, while the maximum values were $1.34 \times 10^{-8}, 1.19 \times 10^{-8}$ and $1.29 \times 10^{-8} \mathrm{~m}^{2} \mathrm{~s}^{-1}$ in the same order of cultivar. The suitability of seven mathematical models to describe the drying behaviour of pomegranate arils was investigated. The models that had the best fit with the highest values of $R^{2}$ and lowest values RMSE in Acco cultivar were the Logarithmic model for all blanched samples and the Page model for unblanched samples. The best-fit models in Herskawitz cultivar were Logarithmic, Page and Midili models amongst the blanched samples and Page model for unblanched sample. Wonderful cultivar had the best fit for Logarithmic and Midili models amongst the blanched samples and Midili model for the unblanched sample. Thus, Logarithmic, Page and Midili models were identified as being more suitable for describing the pomegranate aril drying process for the blanching conditions considered.

Author Contributions: Conceptualization, O.A.F. and U.L.O.; methodology, A.O.A., A.A.T., O.A.F.; software, A.O.A., A.A.T.; formal analysis, A.O.A., A.A.T.; investigation, A.O.A.; resources, O.A.F. and U.L.O.; writing-original draft preparation, A.O.A.; writing-review and editing, O.A.F. and A.A.T. and U.L.O.; supervision, O.A.F., and U.L.O.; project administration, O.A.F.; funding acquisition, O.A.F. and U.L.O. All authors have read and agreed to the published version of the manuscript.

Funding: This research was funded by the National Research Foundation (NRF) of South Africa grant numbers 64813 and 105722, 105483. And the APC was partly funded by Stellenbosch University.

Acknowledgments: This work is based on the research supported by the National Research Foundation (NRF) of South Africa (IUD: 64813 and (IUD: 105722). The financial support of the World Academy of Science and National Research Foundation of South Africa through the award of doctoral scholarship to Adetoro is gratefully acknowledged (IUD: 105483). The opinions, findings and conclusions or recommendations expressed are those of the author(s) alone, and the NRF accepts no liability whatsoever in this regard. 
Conflicts of Interest: The authors declare no conflict of interest.

\section{References}

1. Caleb, O.J.; Opara, U.L.; Witthuhn, C.R. Modified atmosphere packaging of pomegranate fruit and arils: A review. Food Bioprocess Technol. 2012, 5, 15-30. [CrossRef]

2. Fawole, O.A.; Opara, U.L. Effects of maturity status on biochemical concentration, polyphenol composition and antioxidant capacity of pomegranate fruit arils (cv. Bhagwa). S. Afr. J. Bot. 2013, 85, 23-31. [CrossRef]

3. Mphahlele, R.R.; Fawole, O.A.; Stander, M.A.; Opara, U.L. Effect of fruit maturity and growing location on the postharvest concentrations of flavonoids, phenolic acids, vitamin $\mathrm{C}$ and antioxidant activity of pomegranate juice (cv. Wonderful). Sci. Hortic. 2014, 179, 36-45. [CrossRef]

4. Caleb, O.J.; Opara, U.L.; Mahajan, P.V.; Manley, M.; Mokwena, L.; Tredoux, A.G.J. Effect of modified atmosphere packaging and storage temperature on volatile composition and postharvest life of minimally processed pomegranate arils (cvs. "Acco" and "Herskawitz"). Postharvest Biol. Technol. 2013, 79, 54-61. [CrossRef]

5. Ashtiani, S.H.M.; Salarikia, A.; Golzarian, M.R. Analyzing drying characteristics and modeling of thin layers of peppermint leaves under hot-air and infrared treatments. Inf. Process. Agric. 2017, 4, 128-139.

6. Sharma, A.; Thakur, N.S. Influence of active packaging on quality attributes of dried wild pomegranate (Punica granatum L.) arils during storage. J. Nat. Appl. Sci. 2016, 8, 398-404. [CrossRef]

7. Ertekin, C.; Yaldiz, O. Thin layer drying of sliced quash by forced convection. In Proceedings of the 17th World Congress of the International Commission of Agricultural and Biosystems Engineering (CIGR), Qubec, QC, Canada, 13-17 June 2010.

8. Minaei, S.; Motevali, A.; Ahmadi, E.; Azizi, M.H. Mathematical models of drying pomegranate arils in vacuum and microwave dryers. J. Agric. Sci. Technol. 2012, 14, 311-325.

9. Doymaz, I. Drying of pomegranate seeds using infrared radiation. Food Sci. Biotechnol. 2012, 21, 1269-1275. [CrossRef]

10. Calín-Sánchez, Á.; Figiel, A.; Hernández, F.; Melgarejo, P.; Lech, K.; Carbonell-Barrachina, Á.A. Chemical composition, antioxidant capacity, and sensory quality of pomegranate (Punica granatum L.) arils and rind as affected by drying method. Food Bioprocess Technol. 2013, 6, 1644-1654. [CrossRef]

11. Minaei, S.; Motevali, A.; Najafi, G.; Mousavi Seyedi, S.R. Influence of drying methods on activation energy, effective moisture diffusion and drying rate of pomegranate arils ('Punica granatum'). Aust. J. Crop Sci. 2012, 6,584 .

12. Cruz, A.C.; Guiné, R.P.; Gonçalves, J.C. Drying kinetics and product quality for convective drying of apples (cvs. Golden Delicious and Granny Smith). Int. J. Fruit Sci. 2015, 15, 54-78. [CrossRef]

13. Vega-Gálvez, A.; Ah-Hen, K.; Chacana, M.; Vergara, J.; Martínez-Monzó, J.; García-Segovia, P.; Lemus-Mondaca, R.; Di Scala, K. Effect of temperature and air velocity on drying kinetics, antioxidant capacity, total phenolic content, colour, texture and microstructure of apple (var. Granny Smith) slices. Food Chem. 2012, 132, 51-59. [CrossRef] [PubMed]

14. Krokida, M.K.; Maroulis, Z.B. Structural properties of dehydrated products during rehydration. Int. J. Food Sci. Technol. 2001, 36, 529-538. [CrossRef]

15. Aguilera, J.M.; Chiralt, A.; Fito, P. Food dehydration and product structure. Trends Food Sci. Technol. 2003, 14, 432-437. [CrossRef]

16. Doymaz, I. Effect of citric acid and blanching pre-treatments on drying and rehydration of Amasya red apples. Food Bioprod. Process. 2010, 88, 124-132. [CrossRef]

17. Kingsly, A.R.P.; Singh, R.; Goyal, R.K.; Singh, D.B. Thin-layer drying behaviour of organically produced tomato. Am. J. Food Technol. 2007, 2, 71-78.

18. Adetoro, A.O.; Fawole, O.A.; Opara, U.L. Effects of pre-treatment and drying on the quality attributes of fruit. In Proceedings of the VII International Conference on Managing Quality in Chains (MQUIC2017) and II International Symposium on Ornamentals in 1201, Stellenbosch University, Stellenbosch, South Africa, 4-7 September 2017; pp. 1-6.

19. Sabır, A.; Sabır, F.K.; Kara, Z. Effects of modified atmosphere packing and honey dip treatments on quality maintenance of minimally processed grape cv. Razaki (V. vinifera L.) during cold storage. Int. J. Food Sci. Technol. 2011, 48, 312-318. [CrossRef] 
20. Préstamo, G.; Fuster, C.; Risueno, M.C. Effects of blanching and freezing on the structure of carrots cells and their implications for food processing. J. Sci. Food Agric. 1998, 77, 223-229. [CrossRef]

21. Neves, F.I.; Vieira, M.C.; Silva, C.L. Inactivation kinetics of peroxidase in zucchini (Cucurbita pepo L.) by heat and UV-C radiation. Innov. Food Sci. Emerg Technol. 2012, 13, 158-162. [CrossRef]

22. Maghoumi, M.; Gómez, P.A.; Mostofi, Y.; Zamani, Z.; Artés-Hernández, F.; Artés, F. Combined effect of heat treatment, UV-C and super atmospheric oxygen packing on phenolics and browning related enzymes of fresh-cut pomegranate arils. Int. J. Food Sci. Technol. 2013, 54, 389-396.

23. Deylami, M.Z.; Rahman, R.A.; Tan, C.P.; Bakar, J.; Olusegun, L. Effect of blanching on enzyme activity, color change, anthocyanin stability and extractability of mangosteen pericarp: A kinetic study. J. Food Eng. 2016, 178, 12-19. [CrossRef]

24. Mwithiga, G.; Olwal, J.O. The drying kinetics of kale (Brassica oleracea) in a convective hot air dryer. J. Food Eng. 2005, 71, 373-378. [CrossRef]

25. Dincer, I.; Hussain, M.M. Development of a new Biot number and lag factor correlation for drying applications. Int. J. Heat Mass Transf. 2004, 47, 653-658. [CrossRef]

26. Lee, J.H.; Kim, H.J. Vacuum drying kinetics of Asian white radish (Raphanus sativus L.) slices. Int. J Food Sci. Technol. 2009, 42, 180-186. [CrossRef]

27. Arevalo-Pinedo, A.; Fernanda, E.X. Kinetics of vacuum drying of pumpkin (Cucurbita maxima): Modeling with shrinkage. J. Food Eng. 2007, 76, 562-567. [CrossRef]

28. Goyal, R.K.; Mujjeb, O.; Bhargava, V.K. Mathematical modeling of thin layer drying kinetics of apple in tunnel dryer. Int. J. Food Eng. 2008, 4. [CrossRef]

29. Karaaslan, M.; Yilmaz, F.M.; Cesur, O.; Vardin, H.; Ikinci, A.; Coskun Dalgic, A. Drying kinetics and thermal degradation of phenolic compounds and anthocyanins in pomegranate arils dried under vacuum conditions. Int. J. Food Sci. 2014, 49, 595-605. [CrossRef]

30. Wang, J.; Sun, J.; Liao, X.; Chen, F.; Zhao, G.; Wu, J. Mathematical modeling on hot air drying of thin layer apple pomace. Food Res. Int. 2007, 40, 39-46. [CrossRef]

31. Yagcioglu, A.; Degirmencioglu, A.; Cagatay, F. Drying characteristic of laurel leaves under different conditions. In Proceedings of the 7th International Congress on Agricultural Mechanization and Energy, Adana, Turkey, 26-27 May 1999; Faculty of Agriculture, Cukurova University, 1999; pp. 565-569.

32. Diamante, L.M.; Ihns, R.; Savage, G.P.; Vanhanen, L. A new mathematical model for thin layer drying of fruits. Int. J. Food Sci. Technol. 2010, 45, 1956-1962. [CrossRef]

33. Kaleta, A.; Go'rnicki, K. Evaluation of drying models of apple (var. McIntosh) dried in a convective dryer. Int. J. Food Sci. Technol. 2010, 45, 891-898. [CrossRef]

34. Menges, H.O.; Ertekin, C. Mathematical modeling of thin layer drying of golden apples. J. Food Eng. 2005, 77, 119-125. [CrossRef]

35. Doymaz, İ.; Karasu, S.; Baslar, M. Effects of infrared heating on drying kinetics, antioxidant activity, phenolic content, and colour of jujube fruit. J. Food Meas. Charact. 2016, 10, 283-291. [CrossRef]

36. Sarpong, F.; Yu, X.; Zhou, C.; Hongpeng, Y.; Bernard, B.; Junwen, U. Influence of anti-browning agent pretreatment on drying kinetics, enzymes inactivation and other qualities of dried banana (Musa ssp.) under relative humidity-convective air dryer. J. Food Meas. Charact. 2018, 12, 1229-1241. [CrossRef]

37. Movagharnejad, K.; Nikzad, M. Modelling of tomato drying using artificial neural network. Comput. Electron. Agric. 2007, 59, 78-85. [CrossRef]

38. Lopez, A.; Iguaz, A.; Esnoz, A.; Virseda, P. Thin-layer drying behaviour of vegetable wastes from wholesale market. Dry. Technol. 2000, 18, 995-1006. [CrossRef]

39. Dak, M.; Jaaffrey, S.N.A.; Gupta, R.B. Moisture-dependent physical properties of dried pomegranate arils. J. Food Meas. Charact. 2014, 8, 234-240. [CrossRef]

40. Horuz, E.; Maskan, M. Hot air and microwave drying of pomegranate (Punica granatum L.) arils. Int. J. Food Sci. Technol. 2015, 52, 285-293. [CrossRef]

41. Kaya, A.; Aydin, O.; Demirtas, C. Drying kinetics of red delicious apple. Biosyst. Eng. 2007, 96, 517-524. [CrossRef]

42. Andrés, A.; Bilbao, C.; Fito, P. Drying kinetics of apple cylinders under combined hot air-microwave dehydration. J. Food Eng. 2004, 63, 71-78. [CrossRef] 
43. Bilbao, C.; Albors, A.; Gras, M.; Andres, A.; Fito, P. Shrinkage during apple tissue air-drying: Macro and microstructural changes. In Proceedings of the 12th International Drying Symposium (IDS 2000); Elsevier Sciences: Noordwijkerhout, The Netherlands, 2000; ISBN 0-444-50422-2.

44. Tunde-Akintunde, T.Y.; Ogunlakin, G.O. Mathematical modeling of drying of pretreated and untreated pumpkin. Int. J. Food Sci. Technol. 2013, 50, 705-713. [CrossRef]

(C) 2020 by the authors. Licensee MDPI, Basel, Switzerland. This article is an open access article distributed under the terms and conditions of the Creative Commons Attribution (CC BY) license (http://creativecommons.org/licenses/by/4.0/). 